\title{
ASEAN-India Cooperation Project on 'Extent of Transfer of Alien Invasive Organisms in South/Southeast Asia Region by Shipping'
}

\author{
Arga Chandrashekar Anil1,* and Koh Siang Tan ${ }^{2, *}$ \\ ${ }^{1}$ CSIR-National Institute of Oceanography, Dona Paula 403004, Goa, India \\ ${ }^{2}$ St John's Island National Marine Laboratory, Tropical Marine Science Institute, National University of Singapore, 18 Kent Ridge Road, \\ Singapore 119227 \\ *Corresponding authors: acanil@nio.org; tmstanks@nus.edu.sg
}

KEYWORDS

ASEAN-India

Ballast water

Dialogue

Partnership

Regional cooperation

\begin{abstract}
A brief background of events leading to the successful implementation of the first ASEAN-India project on marine sciences is provided. Coordinated by India and Singapore, the project, entitled 'Extent of transfer of alien invasive organisms in South/Southeast Asia region by shipping' served to develop regional cooperation and networks to address the issue of alien invasive organisms, provide training for ASEAN scientists, as well as obtain baseline information on pest species for port management in the light of IMO's Ballast Water Management Convention. The project was completed with an international workshop held in Chiangmai, Thailand where some 29 presentations were made by ASEAN and Indian scientists based on the project activities. A total of 23 original articles are included in this volume. A proposal to implement a second phase of the project was formally submitted to the ASEAN-India Cooperation Fund in 2016.
\end{abstract}

(c) The Author(s) 2018. This article is distributed under a Creative Commons Attribution-ShareAlike 4.0 International license.

\section{INTRODUCTION}

The Association of Southeast Asian Nations (ASEAN) celebrated 25 years of dialogue partnership with India in 2017. A decade earlier in 2007, the formation of the ASEAN-India Science and Technology Development Fund was announced during the $6^{\text {th }}$ ASEAN-India Summit with a contribution of USD 1 million from India. This was quickly followed two years later in 2009 with the setting up of substantially larger ASEAN-India Cooperation Fund, with a contribution of USD 50 million from India to foster deeper and more intense cooperation in a range of sectors in the political, economic and socio-cultural spheres. This was announced at the $7^{\text {th }}$ ASEAN-India Summit in Thailand.

At about the same time, the Ballast Water Management Convention was adopted at the International Maritime Organization in 2004 to prevent the spread of harmful aquatic organisms by shipping. The global transfer of organisms by shipping was identified as one of the major threats to biodiversity conservation and the environment. Many introduced organisms quickly become serious pests in new host countries, with consequent economic losses in mariculture and deleterious effects on threatened marine habitats. Shipping has been identified as one of the major vectors of transfer for invasive species. The problem is expected to accelerate as ships move faster and travel time shortened. This is particularly relevant between South and Southeast Asia, where shipping volume is on the rise.

Southeast Asia has been identified as a major source of xenobiotics to the rest of the world. This in part lies in the enormous biodiversity present in our seas, coupled with expanding economic growth and shipping traffic through the region. However, little is known of the relationship between shipping and biodiversity, making it very difficult to develop and implement effective pest management practices. Given the trans-boundary nature of commercial shipping, research efforts by single nations in the region are often prohibitively expensive to undertake and notoriously ineffective. Shipping in South and Southeast Asia is a critical part of the trade infrastructure and it is necessary for ASEAN and India to address the problem of alien invasions in an informed manner. These major concerns were raised and discussed amongst members of the ASEAN Subcommittee on Marine Science and Technology (SCMSAT) during the $52^{\text {nd }}$ ASEAN Committee of Science and Technology (COST) Meeting held in Kuantan, Malaysia in 2007. With the involvement of the ASEAN-India working group on Science and Technology, this subsequently led to the development of the proposal entitled 'Extent of Transfer of Alien Invasive Organisms in South/Southeast Asia Region by Shipping' for funding consideration by India. The proposal was submitted in 2008 at the $53^{\text {rd }}$ COST in Danang, Vietnam, by the SCMSAT focal point for Singapore Dr Tan Koh Siang, with enthusiastic support from the Chair of SCMSAT and all ASEAN Member States.

The major deliverables of the proposed 3-year project were the following: a) Develop regional cooperation and networks to address the issue of alien invasive organisms arising from shipping, so as to protect regional shipping businesses from external legislative restrictions; b) Provide experience and training for regional scientists through cooperative work; as well as standardised methods between working groups to facilitate data 
sharing; c) Obtain baseline information on pest species that utilise ships as vectors, to enable State Ports to begin to develop relevant control measures.

To take on the enormous biodiversity and paucity of knowledge of marine biology in Southeast Asian seas are in themselves daunting tasks for both scientists and managers attempting to address the issues relating to invasive organisms and shipping. While it was not expected that the project would resolve all issues, the development of functional networks of scientists that can support management in decision-making within ASEAN was envisaged to be a critical step forward. Given India's early and active involvement in the IMO GloBallast Programme (Matheickal, Blonce \& Alonso 2017) as one of the six pilot countries (Campbell 2003; Anil et al. 2004), the partnership between India and ASEAN was timely. The joint undertaking of the proposed baseline study acted as an important starting point in this process.

\section{PROJECT IMPLEMENTATION AND ACHIEVEMENTS}

\subsection{Inaugural meeting}

The project was approved by India in April 2010 with funding from the ASEAN-India Cooperation Fund. Dr A. C. Anil, Chief Scientist at the National Institute of Oceanography (NIO) in Goa was appointed to be the Indian Coordinator and Dr Tan Koh Siang, Coordinator for ASEAN. Our first meeting for project participants was held between $14^{\text {th }}$ and $15^{\text {th }}$ December of the same year at a hill station in Munnar, Kerala State, India, hosted by the National Institute of Oceanography, Goa. The Chief Technical Advisor to IMO GloBallast Programme Dr Jose Matheickal was also in attendance together with representatives from eight ASEAN Member States (Figure 1).

\subsection{Training workshops and mid-term review}

A series of short training workshops was organized in India and Singapore (Figure 2) to train and familiarize ASEAN participants in the principles and techniques for detecting alien species on ships and in ports. Methods for sampling ballast water and marine growth on ship hulls and sea chests were discussed during the first training workshop held in Singapore from 19 to 20 July 2011

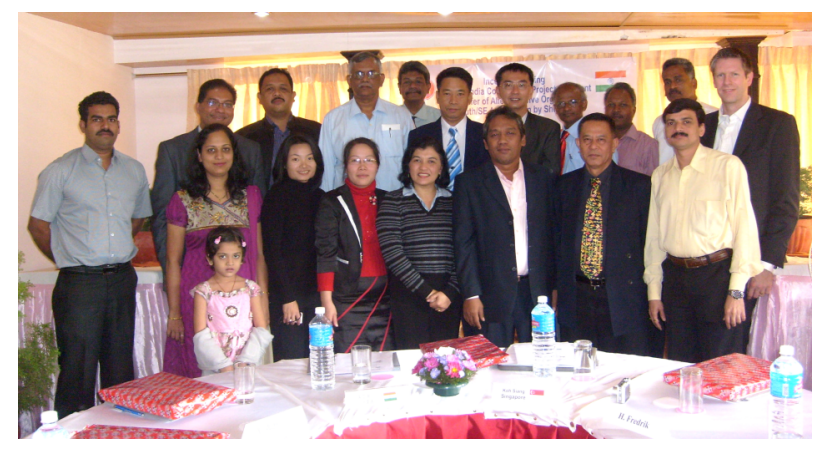

Figure 1. Participants at the inaugural meeting of the ASEAN-India Cooperation Project on 'Extent of Transfer of Alien Invasive Organisms in South/Southeast Asia Region by Shipping' held between 14-15 December 2010 in Munnar, Kerala State, India, hosted by the National Institute of Oceanography, Goa. Front row (L-R): Lidita Khandeparker (with daughter; India), Serina Lee (Singapore), Le Thi Hoang Mai (Vietnam), Sumana Kajonwattanakul (Thailand), Dirhamsyah (Indonesia), Cesar Pagdilao (Philippines), Dattesh Desai (India); back row (L-R): Kaushal E. Mapari (India), Jose Mathieckal (IMO), Shahruddin bin Yusof (Malaysia), Arga C. Anil (India), Venkat Krishnamurthy (India), Aung Moe (Myanmar), Tan Koh Siang (Singapore), Subhash S. Sawant (India), P. Vethamony (India), T. V. Raveendran (India), Fredrik Haag (IMO).
(Figure 2B). Recognition and identification of alien bivalves already prevalent in the region was the subject of the second training workshop conducted in Visakhapatnam, India, held from 22 to 23 February 2012 (Figure 2C). The third workshop, held in Singapore from 4 to 5 March 2013 focused on statistical methods covering scientific methods and ecology, statistical inference and multivariate statistics, and model building. A mid-term review of the project was also organized in Puncak, near Bogor, Indonesia between 11 and 12 September 2012 (Figure 2A), with the kind support of Dr Dirhamsyah, SCMSAT focal point for Indonesia at the Research Center for Oceanography, Indonesian Institute of Sciences (LIPI).

\subsection{Port and ballast water sampling; fouling panel and bacterial profiling}

The project provided the opportunity for each participating country to carry out ballast water and port water sampling and put into practice the recommended methods and techniques in local conditions. However, in order to kick-start an assessment of organisms in port areas, participants agreed during the first training workshop to conduct a 1year study of marine growth on PVC panel surfaces in a port of their choice. This will allow the participants to familiarize themselves with the kinds of marine organisms that settle on new surfaces in local ports, as well as determine the growth and seasonality of settlement over a 12-month period. If alien invasive species are present, the likelihood of detecting them on such panels is also enhanced.

Bacterial profiling of port and ballast water was kindly made available through NIO in Goa. ASEAN participants were able to send preserved seawater samples to
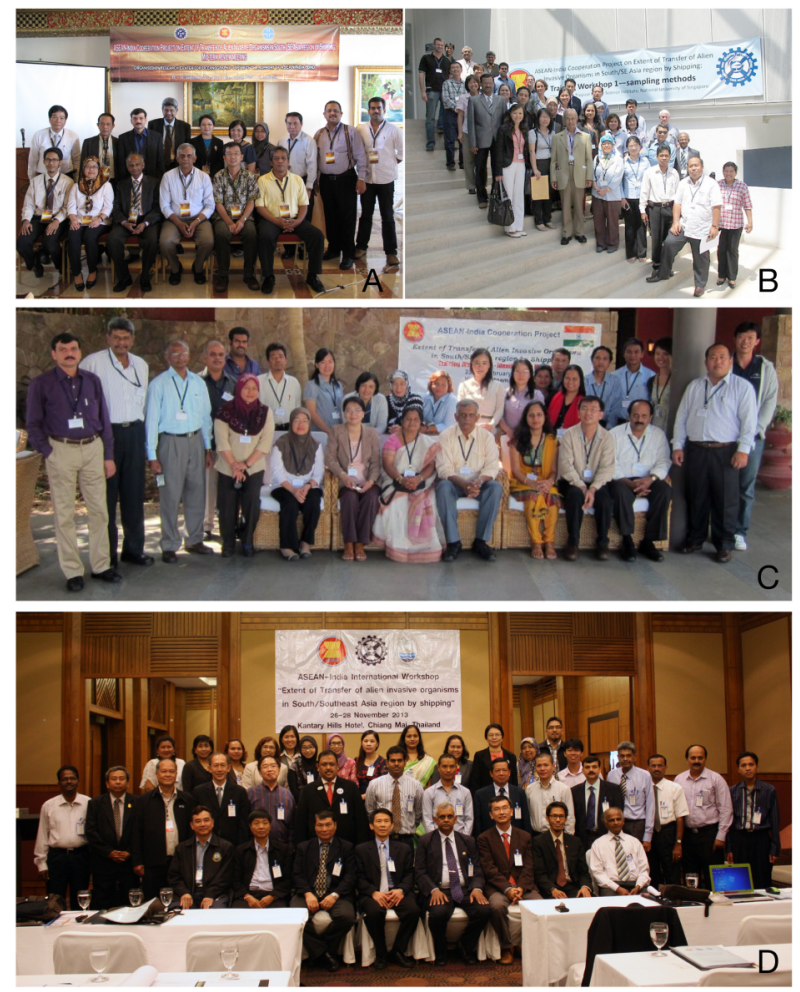

Figure 2. Participants at the mid-term review, training workshops and conference held during the course of the ASEAN-India Cooperation Project on 'Extent of Transfer of Alien Invasive Organisms in South/Southeast Asia Region by Shipping', 2010-2013. (A) Mid-term review held in Puncak, Indonesia; (B) First training workshop on sampling methods held in Singapore; (C) Second training workshop on identification methods held in Visakhapatnam, India; (D) joint ASEANIndia International Workshop on marine alien invasives of the ASEANIndia Cooperation Project held in Chiang Mai, Thailand. 
NIO to obtain a preliminary assessment of the kinds of acteria present in each country.

The results of these studies are reported by Khandeparker et al. (2018) and Lim et al. (2018) in this volume.

\subsection{Chiang Mai International Workshop and Proceedings}

The joint ASEAN-India International Workshop on marine alien invasives of the ASEAN-India Cooperation Project was held in Chiang Mai, Thailand from $26^{\text {th }}$ to $28^{\text {th }}$ November 2013 (Figure 2D). The workshop was hosted by the Department of Marine and Coastal Resources (DM$\mathrm{CR}$ ), Ministry of Natural Resources and Environment, Thailand and co-chaired by Dr Sombat Poovachiranon (DMCR, Thailand), Dr A. C. Anil (National Institute of Oceanography, India), and Dr K. S. Tan (Tropical Marine Science Institute, National University of Singapore). Participants from Brunei Darussalam, India, Indonesia, Lao PDR, Malaysia, Myanmar, Philippines, Singapore, Thailand, Vietnam and ASEAN Secretariat were present. Sessions on (a) Bioinvasions; (b) Port Biological Baselines; (c) Ballast Water Management; and (d) Biofouling Management, were held over two days. Apart from three keynote addresses, 29 oral presentations were made in five sessions, in addition to country reports from the respective participants. This was a rare opportunity for scientists interested in marine alien invasives from ASEAN and India to come together in person to share their experiences in conducting similar research in their respective countries. Many of the presentations, as well as a part of the results of the fouling panel immersion observations in selected ASEAN ports of call, are included here in this volume as part of the proceedings.

\section{THE NEXT PHASE}

Since the ASEAN-India project proposal was submitted in 2008, Indonesia, Malaysia and Singapore have ratified the Ballast Water Convention. The Convention itself came into force in September 2017, 13 years after adoption at the IMO. While India and the majority of ASEAN Member States have yet to ratify the Convention, neither Indonesia, Malaysia nor Singapore has implemented the Convention. Port biological baseline surveys in ASEAN have also been slow to get off the ground. The idea to continue the project as a second phase was discussed briefly during the project mid-term review held in Puncak, Java, Indonesia between 11 and 12 September 2012. The meeting was hosted and co-chaired by Dr Dirhamsyah, SCMSAT focal point for Indonesia with project coordinators Dr A.C. Anil (India) and Dr Tan Koh Siang (Singapore). During the final meeting of the project held in Goa, India from 13 to 14 July 2016, a 'Phase 2' proposal was conceived, which was entitled 'Extent of transfer of alien invasive organisms in South/Southeast Asia by shipping. Phase II. Towards an ASEAN-India exemption zone'. The principal objective was to prepare ASEAN countries and India for a proposed establishment of a maritime exemption zone for ballast water exchange in South/Southeast Asia. This included activities to establish a regional risk assessment framework for the transfer of alien invasive species by shipping, while enhancing scientific expertise among South/Southeast Asian Port states to address issues relating to marine invasive organisms and support management in decision making. A programme to enhance public awareness, and the establishment of an ASEAN-India postgraduate exchange-training scheme, were also in- cluded in the proposal. The proposal, at the time of writing, is under consideration for funding by the ASEAN-India Cooperation Fund.

\section{CONCLUSIONS}

ASEAN countries and India have over the past several years worked together through SCMSAT to establish close ties between scientists from the region. Through training workshops and joint research with CSIR National Institute of Oceanography in Goa, India, the ASEAN-India Cooperation project has fostered excellent working relationships between participating scientists for the first time to conduct marine research at a truly regional level to address issues related to the transfer of harmful and pest species by vessels. The proposed project in its second phase intends to ride on this new network of scientific cooperation to further enhance and strengthen this cooperative framework of marine science, with the aim of establishing an exemption zone within the ASEANIndia region vis-à-vis IMO Ballast Water Convention. The Convention, which is now in force, requires all vessels traveling between international ports to have ballast water treatment systems to treat ballast water. At the same time, the Convention also has provisions (Regulation A-4) for exemption zones to be implemented if ships operate exclusively within the established zone, i.e., ships need not adhere to the treatment requirements of the Convention. There are substantial economic implications for both port and ship operators alike, if such exemption zones become operational. However, countries must be assured that the risk of transfer of unwanted organisms is minimal across the exemption zone. The establishment of close ties amongst working scientists in ASEAN and India over the last several years during project implementation has put us in good stead for the next phase of this project.

\section{ACKNOWLEDGEMENTS}

We would like to express our sincere gratitude and thanks to the many people who have enthusiastically supported and endorsed this project from conception to realization. In particular we are grateful to all Indian and ASEAN participants who have contributed to the project: Brunei- Desimawati Metali, Ranimah Wahab, Zuliza Jolkifli, , Noorizan Hj. Abdul Karim; Cambodia-Hem Bonarin, Meas Rithy, Eng Kim San, Chuop Sivutha, Sok Sothea, Srey Sunleang; India- M. Balaji, G. Dharani, Dattesh Desai, Temjensangba Imchen, Lidita Khandeparker, Venkat Krishnamurthy, Kaushal Mapari, C. Rivonker, Subhash Sawant, R.K. Sharma, V. Venugopalan; Indonesia-Dirhamsyah, Hadiyanto, Hikmah Thoha, Sofia Yuniar Sani, Deny Sutisno; Lao PDR-Vanseng Chounlamany, Kongneun Chounlamoutry, Soukaseum Dalasand; Chanlakhone Homkingkeo; Somphone Khongsab, Chanda Vongsombath; Malaysia-Hing Lee Siang, Nadiah Fatin, Nazuki Sulong, Shahruddin Yusof, Zaharuddin M. Maideen; Myanmar- Myint Myint Khaing, Aung Moe, Soe Naing, U Kyaw San; Philippines-Mari-Ann Acedera, Nero Austero, Rhodora Azanza, Ian Fontanilla, Hildie Nacorda, Cesar Pagdilao (deceased); Singapore-Evelyn Chong, Guillaume Drillet, Serina Lee, Sandric Leong, Leong Yi Lin, Lim Chin Sing, Youna Lyons, Sin Tsai Min (deceased), Teresa Tay, Serena Teo, Zafrul Alam; Thailand-Ratchanee Puttapreecha, Sumana Kajonwattanakul, Suree Satapoomin, Ukkrit Satapoomin, Wannakiat Thubthim- 
sang; Vietnam-Le Hoang Mai, Bui Thi Diem Phuong, Nguyen Van $\mathrm{Cu}$, Tran Thanh Thuy, Vu Thi Hai Van. We are also appreciative of the constant attention provided by SCMSAT focal points of ASEAN Member States and the ASEAN Secretariat, including Mr Dimas Adekhrisna who has provided much needed advice to keep the project on an even keel.

\section{REFERENCES}

Anil AC, Clarke C, Hayes T, Hilliard R, Joshi G, Krishnamurthy V, Polglaze J, Sawant SS, Raaymakers S. 2004. Ballast water risk assessment, Ports of Mumbai and Jawaharlal Nehru, India, October 2003: Final Report. GloBallast Monograph Series No. 11. London: International Maritime Organization.

Campbell ML. 2003. Training and capacity building, lessons, future needs and directions for the International Maritime Organisation GloBallast Port Survey Program. $1^{\text {st }}$ International Workshop on Guidelines \& Standards for Invasive Aquatic Species Surveys \& Monitoring; 2003 Apr 13-17; Arraial do Cabo, Brazil.

Khandeparker L, Desai DV, Anil AC, Sawant SS, Venkat K, Kaushal M, Jolkifli Z, Karim, NA, Thoha H, Hadiyanto, Dalasane S, Chounlamountry K, Khaing MM, Dungca
JC, Azanza R, Lim CS, Tan KS, Kajonwattanakul S, Phuttapreecha R, Le HM. 2018. Application of fluorescence in situ hybridization-flow cytometry (FISH-FCM) technique to detect and quantify Vibrio cholerae populations from different geographic regions. ASEAN Journal on Science and Technology for Development 35(1-2):159-164.

Lim CS, Jolkifli Z, Jair A, Karim NA, Wahab RA, Desai DV, Venkat K, Khandeparker L, Kaushal M, Sawant SS, Anil AC, Sawant SS, Thoha H, Hadiyanto, Dirhamsyah, Dalasane S, Chounlamountry K, Hing LS, Yusof SH, Khaing MM, Nacorda HME, Austero N, Azanza R, Pagdilao C, Kajonwattanakul S, Phuttapreecha R, Poovachiranon S, Le HM, Tran TT, Nguyen VC, Tan KS, Anil AC. 2018. An intersite study of biofouling recruitment on static immersion panels in major ports of Southeast Asia and India. ASEAN Journal on Science and Technology for Development 35(1-2):165-174.

Matheickal J, Blonce A, Alonso J. 2017. The GloBallast story: reflections from a global family. Partnerships to catalyze transformational innovations in marine biosafety'. GloBallast Monograph Series No. 25. London: GEF-UNDP-IMO GloBallast Partnerships. 